Engineering History and Heritage Volume 164 Issue EH3

John Rennie and Waterloo Bridge, London Ruddock
Proceedings of the Institution of Civil Engineers

Engineering History and Heritage 164 August 2011 Issue EH3

Pages 155-162 doi: 10.1680/ehah.2011.164.3.155

Paper 1100011

Received 14/03/2011_ Accepted 26/04/2011

Keywords: biography/bridges

\title{
John Rennie and Waterloo Bridge, London, UK
}

Ted Ruddock MBE, BA, MAl, MSc(Eng), CEng, MICE

Retired, Edinburgh, UK

Among the wide range of civil engineering works undertaken by John Rennie were a number of elegant masonry arch bridges, the finest of which being Waterloo Bridge in London, UK. This paper looks briefly at some of the significant masonry bridges in Rennie's earlier career, to indicate his experience up to 1809 when he became involved with Waterloo Bridge. It then describes in more detail the design and construction of the bridge, and the constraints and problems that Rennie had to deal with in the process.

\section{Introduction}

Although a few substantial masonry arch bridges were subsequently constructed to his design, John Rennie's Waterloo Bridge can fairly be considered to be the peak of his achievement in that class of work (Figure 1). It was built by Jolliffe \& Banks (Skempton et al., 2002: 35-39) in 1811-1817, under what was easily the largest bridge contract yet undertaken in Britain. Samuel Smiles considered that it was 'indeed a noble work, and probably has not its equal for magnitude, beauty and solidity' (Smiles, 1862: p. 187).

Although trained as a millwright, Rennie was interested in bridges from an early stage. His son tells the story (Rennie, 1784), repeated by Smiles (1862: p. 130), of his father superintending his first bridge in 1784. This has subsequently been found to be incorrect, but probably does reflect some involvement in the project. That was indeed the year when Rennie set off on horseback to visit some of the engineering works in progress in England, heading for Birmingham where he could meet Matthew Boulton and James Watt. On the way there he stopped at several bridges, but particularly at Lancaster to look at Thomas Harrison's Skerton Bridge, which was then under construction. It was the first multi-arch bridge in Britain to have a level roadway along its length, and the elevations were adorned by coupled Doric columns with pediments above. Rennie was sufficiently impressed to make a sketch of it in his notebook (NLS, 1784).

After he had returned north, Boulton and Watt offered him the job of managing the Albion flour mills on the south bank of the Thames in London, and for the next few years his career was occupied principally by what is now termed mechanical engineering. Nevertheless, he was involved from 1789 in surveys for canals, at first without success in seeing them come to fruition, but in 1792 obtaining an Act of parliament for the Lancaster canal. This provided him with the opportunity to design his first large bridge, an aqueduct to carry the canal over the River Lune, a mile upriver from the Skerton Bridge he had visited 8 years earlier. The river here was about $400 \mathrm{ft}(120 \mathrm{~m})$ wide and the canal was to be $63 \mathrm{ft}(19 \cdot 2 \mathrm{~m})$ above the river. Rennie chose to cross it with a structure with five $70 \mathrm{ft}(21.3 \mathrm{~m})$ masonry arches, almost semi-circular in shape. In its architectural treatment, Rennie already displayed a sure touch. Because the canal gave a horizontal line to the entablature, he deployed a unique variation on classical motifs. Over the centre arch is a large tablet with an inscription in Latin and the names of the designer and contractors - the only occasion when Rennie allowed his name to appear on a finished structure.

Although externally the voussoirs are of constant depth with a dripmould above them, internally the arch rings increase in thickness from the crown of the arch down, until about halfway down they increase significantly and split into two, so that the upper part forms an inverted arch between adjacent spans. This change to the design was introduced by Rennie in February 1795, 8 months after the contract had been signed, although before work had started on the superstructure. It appears to have been his own idea and has not generally been used by other engineers. Nevertheless, he put great store by it and used it on subsequent multi-arch bridges, including Waterloo. Another structural feature of the Lune aqueduct that Rennie included in his later major bridges was longitudinal voids in the spandrels of the arches; they were introduced by John Smeaton at Perth Bridge in the 1760s (Ruddock, 1974), but Rennie was the first British engineer to use them consistently.

His next two masonry bridges were also aqueducts, in this case for the Kennet and Avon canal over the River Avon southeast of Bath. Each has three arches and, although structurally similar to the Lune aqueduct, they are architecturally different from it and from each other. The central arch of Avoncliff aqueduct is semielliptical and the side arches semi-circular, but the entablature is again an invention of Rennie's own, a simplified version of the Corinthian order. Dundas aqueduct has a central semi-circular 
John Rennie and Waterloo

Bridge, London

Ruddock

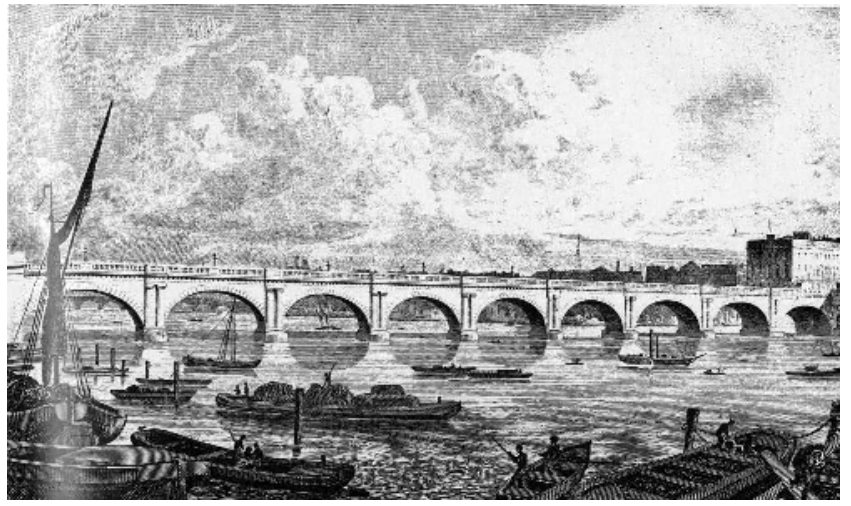

Figure 1. Waterloo Bridge

arch of $64 \mathrm{ft}(19 \cdot 5 \mathrm{~m})$ span, flanked by parabolic arches with their principal axis vertical. The architectural treatment here is a much more correct exercise in the Doric order than at Lune. Unfortunately, the stone for both of these aqueducts came from the company's own quarries and weathered badly over the years, requiring a lot of patching.

\section{Wolseley Bridge}

Rennie's first major road bridge was Wolseley Bridge over the River Trent at Colwich (Figure 2). Severe floods in February 1795 had swept away the old structure and many others and, at the translation sessions of 1797, Staffordshire JPs approved Rennie's design for a replacement. The river here is in a flood plain and the approaches to the bridge not much above it, so Rennie opted for a three-arch bridge with a road line rising in a gentle curve to its centre. Classical adornment would have been inappropriate to this, so he provided pilasters with apsidal niches over the piers and a bullnose stringcourse to pick out the line of the road.

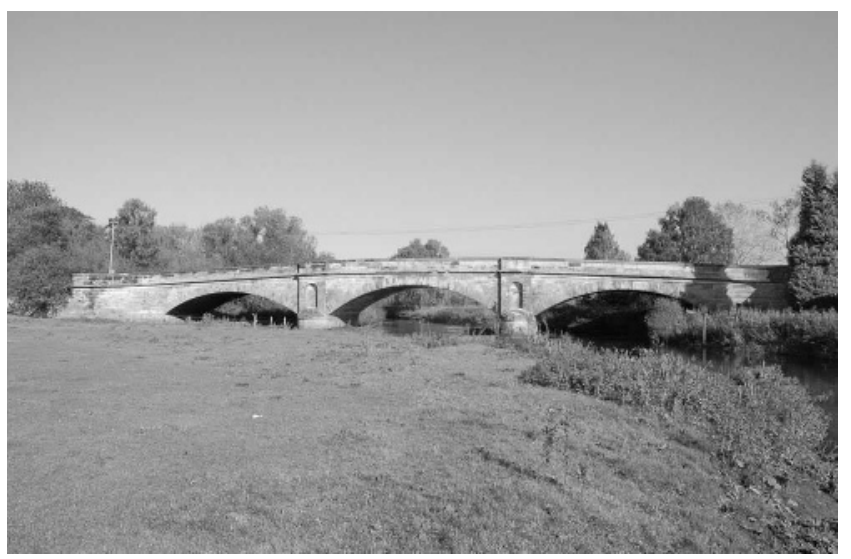

Figure 2. Wolseley Bridge
At the aqueducts mentioned above, the foundations had been built by direct labour under the supervision of the resident engineer - at Lancaster after a change of heart by the contractor and on the Kennet and Avon because no contractor could be found who was willing to undertake them. At Wolseley Bridge, Rennie's insistence on adherence to his detailed specification, administered by Joseph Potter as resident engineer, caused not one but two experienced contractors to abandon the work, and reinforced Rennie's opinion that foundations were too important to be left to contractors and were best undertaken at day rates by workmen employed by the client. Although Wolseley Bridge exceeded the estimate, partly because of these problems, the county continued for some years more to employ Rennie for its larger bridges. One of these was Radford Bridge over the River Penk just outside Stafford. The bridge is towards the lower end of a long, gentle climb, but Rennie never built a bridge whose elevation was not symmetrical. To accommodate this, the road levels out over the bridge then climbs again; the piers of the bridge are surmounted by twin Doric columns and there is a dentilated stringcourse.

\section{Kelso Bridge}

These were features that he had included in another larger bridge a few years earlier. Another great flood, in October 1797, had damaged the bridge over the River Tweed at Kelso so severely that, on Rennie's advice, it was decided to rebuild. The Tweed receives the substantial River Teviot just above the town and then makes a large bend past the town, so Rennie had the river bed surveyed at six different locations to find the best site for the bridge, having regard both to the composition of the river bed and the current in the river. When that was settled, he designed a bridge with five semi-elliptical arches of $72 \mathrm{ft}(21.9 \mathrm{~m})$ span (Figure 3). Clearly meant to provide a grand approach to the town, it would have a level roadway, which necessitated a substantial, and therefore expensive, embankment across to higher land on the south side. Despite a letter from Rennie urging the bridge trustees to construct the foundations themselves, the whole structure was built in 1800 04 in a single contract, with a resident engineer recommended by Rennie. As at Wolseley, the ends of the cutwaters were semi-circular in plan, a shape that Rennie later discarded in favour of curved-pointed. An innovation at Kelso though was that the arch rings on the external face increased in depth from the crown to the springings, rather than only internally as had been the case at Lancaster. The inverted arches between the main arches, however, were not expressed externally, here or in any other of Rennie's masonry bridges.

\section{Waterloo Bridge}

Thus when in 1806 a proposal was brought forward for a new bridge across the River Thames in London by a group of promoters called the Strand Bridge Company, Rennie had considerable experience of designing substantial masonry arch bridges. The Strand Bridge scheme was based on a design by 
Engineering History and Heritage

Volume 164 Issue EH3
John Rennie and Waterloo

Bridge, London

Ruddock

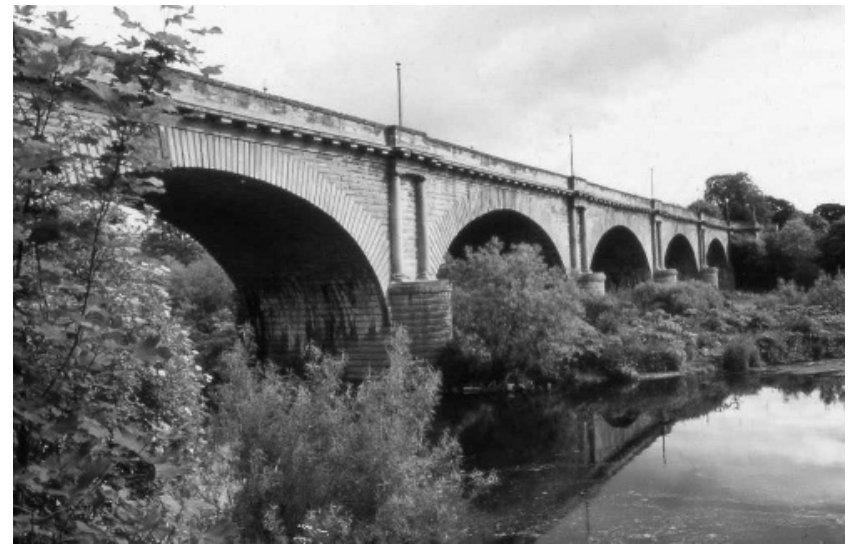

Figure 3. Kelso Bridge

George Dodd (Skempton et al., 2002: 183-184), one of a family of speculative engineers whose completed works amount to very little. More detailed plans were issued in 1807 but the plan failed to gain parliamentary approval in 1808 . Because of worries about Dodd's lack of experience in projects of this magnitude, his plans were referred to Rennie and William Jessop for a second opinion on 12 January 1809. Though he had been the leading canal engineer of the 1790s, the choice of Jessop was slightly odd as masonry bridges were not his forté. The pairing with Rennie must have been interesting, too, because although they had cooperated several times on canal schemes they had subsequently disagreed publicly on the relative importance of economy and durability in civil engineering works. Nevertheless, they produced a joint report on 20 February (ICE, 1809: 155-165). They noted that Dodd's plans, elevations and sketches differed considerably in form and dimensions from each other - not a good start - so they took his estimate as their guide. From this it appeared that there were to be nine arches of $130 \mathrm{ft}$ ( $39.6 \mathrm{~m})$ span, modelled closely on Perronet's bridge over the River Seine at Neuilly. Clearly, if an equal degree of skill was exercised, such a bridge could be built in London. They agreed with Dodd's idea of a few, flat arches as being least likely to impede navigation on the river, but did not approve his use of Perronet's 'compound curves' - an ellipse for the main body of the arch, flaring out to a segment of a circle on the external elevation. Of particular concern was the fact that when the centres were struck at Neuilly, the crowns of the arches had sunk substantially and the spandrels had risen, which offended Rennie's notions of an equilibrated arch. They also noted that the crowns of Dodd's arches were $3 \mathrm{ft}(0 \cdot 91 \mathrm{~m})$ lower than those of Westminster Bridge, thus restricting navigation to some extent. After some more, detailed criticisms they objected to the use of Portland stone as being insufficiently durable, particularly for those parts in water, and recommended the use of Dundee stone, commenting: 'The expense no doubt will be greater than Portland, but their superior fitness for such a work \& their superior durability will in our mind far more than compensate for the difference of expense' (ICE, 1809). Taking their own detailed alterations into account and updating the costs of some elements of Blackfriars Bridge, they reworked the estimate for Dodd's bridge to be $£ 444000$.

The promoters meanwhile had returned to parliament and were successful this time in gaining their Act on 20 June 1809. It laid down certain parameters that constrained the design. The clear waterway was not to be less than $1080 \mathrm{ft}(329 \cdot 2 \mathrm{~m})$ and the arches not less than $120 \mathrm{ft}(36.6 \mathrm{~m})$ span. The arches of Westminster and Blackfriars Bridges each decreased in span from the centre to the abutments, but the Strand Bridge would have to leave the river at a much higher level than the ground on the Surrey side, necessitating either a long approach viaduct or a short steep pull. At the Middlesex (western) end the roadway was not to come nearer to Somerset House than $60 \mathrm{ft}(18 \cdot 3 \mathrm{~m})$.

Little progress was made until a year later when Rennie was appointed engineer to the company. Even at this late stage, the precise line of the bridge was not fixed. Dodd's plans were inaccurate and so almost immediately Rennie had the area resurveyed, paying particular attention to the direction of the current in the river in order that the bridge should cross it as nearly as right angles as possible. Because of Somerset House, the west end could move little, but by early October 1810 he had settled on a line that landed on the Surrey side $40 \mathrm{ft}(12.2 \mathrm{~m})$ further west than before. The Middlesex abutment had been moved to bring it into line with the arcade of Somerset Place (the topography of the area was later changed drastically by the construction of the Victoria embankment). The possibility of eight arches each of $135 \mathrm{ft}(41 \cdot 1 \mathrm{~m})$ span had been dismissed, probably on aesthetic grounds, as had graduated arches from $145 \mathrm{ft}(44.2 \mathrm{~m})$ down to $120 \mathrm{ft}(36.6 \mathrm{~m})$ because of the additional cost of centres to suit the different sizes of arches. The form of the bridge followed Rennie's earlier practice (Figure 4).

The first pile for the cofferdam for the Surrey abutment was driven on 1 March 1811. There were two rows of 6 in $(152 \mathrm{~mm})$ thick by 12 in $(305 \mathrm{~mm})$ wide Dantzic or Memel timber piles, with one 12 in by 12 in pile every $8 \mathrm{ft}(2.4 \mathrm{~m})$. The ground consisted of $1 \mathrm{ft}(305 \mathrm{~mm})$ of mud, then gravel to a good stiff clay. Rams 7-11 cwt $(355 \cdot 6-558 \cdot 8 \mathrm{~kg})$, worked by four men, were raised 28-30 ft $(8 \cdot 5-9 \cdot 1 \mathrm{~m})$; the piles were driven to a depth of $16 \mathrm{ft}(4.9 \mathrm{~m})$. The space between the rows of piles was filled with grey stock bricks on puddle and covered in Thames gravel, and piles were caulked with hemp or oakum. Two $6 \mathrm{hp}(4 \cdot 4 \mathrm{~kW})$ pumps were installed to pump out the water; they proved to be more than sufficient and, later, a single $10 \mathrm{hp}(7 \cdot 4 \mathrm{~kW})$ pump was placed on piles to work an Archimedes screw. With the cofferdam dewatered, the ground inside was excavated about 9 or $10 \mathrm{ft}(2 \cdot 7-3 \cdot 0 \mathrm{~m})$. From the reduced ground level, beech or elm 12 in $(305 \mathrm{~mm})$ diameter bearing piles were driven $14 \mathrm{ft}$ $(4.3 \mathrm{~m})$, their heads sawn off, and elm or beech beams 9 in deep 
John Rennie and Waterloo

Bridge, London

Ruddock

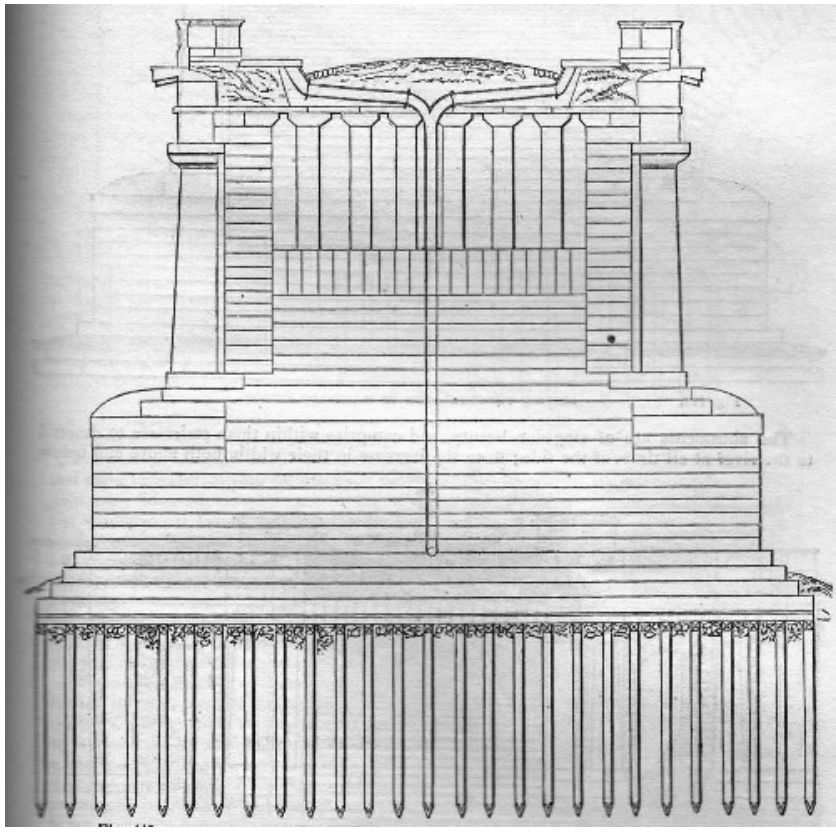

Figure 4. Section through pier of Waterloo Bridge (Cresy, 1847)

(229 mm) nailed down to the heads of piles. Kentish ragstone was placed between, then another 9 in layer laid crosswise, also filled with Kentish ragstone, then a final 5 in $(127 \mathrm{~mm})$ layer. This cofferdam was completed in July (NLS, 1811) and the masonry was finished on 18 January 1812.

By June 1812, Rennie was able to report to the committee that the water had been shut out of the cofferdam for the first pier (the engineers' reports always counted from the Surrey side) on 4 December 1811. The steam engine had been fixed on the cofferdam on 10 January. The foundation was prepared in a similar manner to the abutment, and completed on 10 March. Meanwhile cofferdams for the next piers were progressing, with the fourth pier cofferdam begun on 1 May, and a start on the first arch was expected later in June. Rennie also stated that he expected to complete the arches by November 1815 and to have the bridge passable shortly thereafter (ICE, 1812a).

Despite the steady progress, the committee asked Rennie to consider using cast iron for the superstructure instead of stone, in order to save cost. He replied:

The Strand Bridge being placed in the heart of the metropolis and where the thoroughfare of course must be immense ought to be executed in the most substantial manner having also due regard to the free and uninterrupted passage for the navigation of barges and other craft under it and likewise to the magnificence suitable to the metropolis of the British Empire.

Given the restrictions placed on the company by its Act, he thought that a bridge designed along similar lines to
Southwark Bridge (still under consideration) would cost $£ 470$ 742 plus $£ 30000$ of useless work already done (ICE, 1812b). Unusually, he gave no explanation of how he had arrived at these figures, nor did he give any for iron arches of $120 \mathrm{ft}$ $(36.6 \mathrm{~m})$ span (the largest arch at Southwark would be twice that). It is hard to escape the belief that he was as much concerned with the bridge's magnificence as its cost.

By December 1812, when work should have started on the eighth (Middlesex) pier, it had been delayed by the need to make arrangements with the Duchy of Lancaster, who owned the land that was required and whose chancellor had recently died; however, Rennie expected the contractors to make up lost time next season. Another problem that had delayed the works had occurred in the foundations of the third pier. That part of the river had been dredged from time immemorial to supply sand for the bricklayers and masons of London, and some of these pits had been backfilled. Many human skulls were found and the foundation had required extra piling. Another setback had been the tide of 21 October, which had overtopped the third and fourth pier cofferdams; it took 5 days to pump the water out and make good. Nevertheless, four courses of arch stones had been built on the south abutment and first and second piers and the centres for the arches were beginning to be framed. Work was also progressing on a temporary access bridge to span across the tops of the eastern salient points of the piers, and Rennie was happy to report that no accident had occurred (ICE, 1812c).

Six months later, access had been gained to the eighth pier, but quicksand had been found under it. The cofferdam for the Middlesex abutment had been finished on 27 February, but had encountered difficulty with the foundations of buildings in Somerset Place next door. They had actually been laid on top of quicksand, and as the bridge foundations were $6 \mathrm{ft}(1.8 \mathrm{~m})$ lower, there had been a tendency for the buildings to move. Rennie noted that considerable cracks had existed before work on the bridge commenced.

The first rib of the centre for the Surrey arch had been set on 9 March 1813 (Figure 5). Rennie's eldest son George kept a diary of the works, and he noted that this was (NLS, 1813):

... to be done in a novel \& unprecedented manner but not without considerable apprehensions on the part of the contractors, Messrs Joliffe \& Banks. The idea was no less than to place the ribs singly on their several tressles \& supports. Each rib was calculated to weigh about 40 tons, the raising of which weight indepen ${ }^{t}$ of their prodigious bulk was justly considered as hazardous. As the method if successful promised many advantages, it was finally determined upon ...

Each rib was assembled on the bank of the river, then slid down a greased inclined plane to the deck of three barges lashed together. Two derricks then raised the rib to butt against a frame 7-8 ft 
Engineering History and Heritage

Volume 164 Issue EH3
John Rennie and Waterloo

Bridge, London

Ruddock

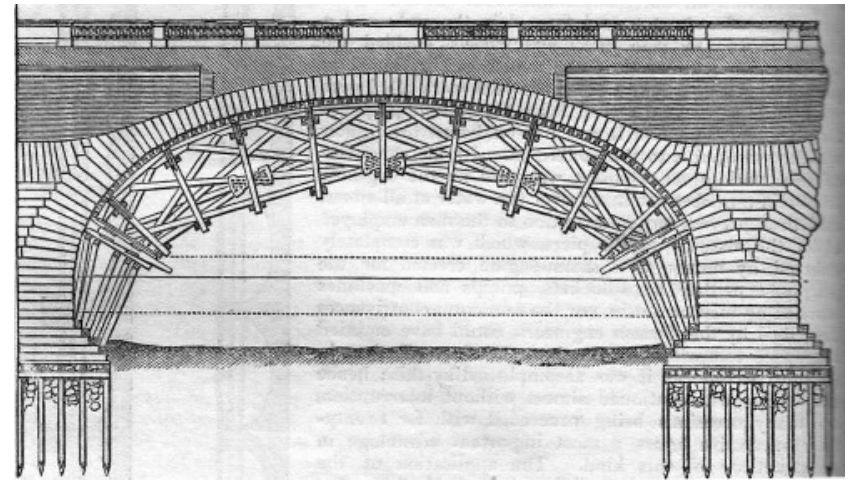

Figure 5. Centring for Waterloo Bridge: some of the longer members socketed into cast iron shoes (Cresy, 1847)

$(2 \cdot 1-2 \cdot 4 \mathrm{~m})$ high that had been prepared on top of the deck, with the extremities of the rib protruding over the sides. When all was ready, the barges were floated downstream on a flood tide and the rib settled in position as the tide ebbed. This operation was repeated for each of the eight ribs by 10 April, and the centre was completed with its lagging by 30 April (ICE, 1813a).

About this time, the decision was taken to build all of the foundations in cofferdams. Westminster Bridge and Blackfriars Bridge, the two 'modern' bridges over the river, had both used caissons and it had been intended to use caissons for the four northern piers here. Although it had been necessary to drive a third ring of sheet piling for the eighth pier to keep the dam watertight, Rennie considered that cofferdams gave a greater certainty of providing a secure foundation and were therefore preferable.

Back at the Surrey end, construction of the arches was under way. There were 105 stones in each archring, and 15 stones laid header and stretcher in the $45 \mathrm{ft}(13.7 \mathrm{~m})$ width of the bridge. Progress was halted at the tenth course so that the next arch could catch up and the inverted arch between the main arches built without exerting out-of-balance pressure (Figure 6).

The meeting of the company on 10 June 1813 passed a resolution that Rennie, rightly, interpreted as an indirect censure on him. He was in the habit, as the contract allowed, of giving instructions to contractors for additional works without consulting the committee. A particular example was the extracting of the sheet piles 'at the expense of the Company' when the cofferdams were removed. In reply, Rennie explained that Jolliffe \& Banks had included $£ 2756.16$.0 in their tender for this, which he had felt was too high, so it had been omitted from the contract. When they did the work on his instructions, presumably at day rates, it had cost $£ 483.4 .0$ less than they had quoted.
He also pointed out that extra works might need to be undertaken without waiting for a committee meeting if delays and consequential extra costs were to be avoided, but agreed that he would seek the committee's approval to extras that were not urgent. There was a sting in the tail, though; the committee would have to take responsibility for all such decisions (ICE, 1813b).

Having fended off the committee, Rennie now had to deal with the contractors. He wrote to them clearly that no work would be deemed extra to the contract (and therefore eligible for additional payment) without a specific instruction. The division of responsibility for the temporary works is interesting. He had also repeatedly asked Jolliffe \& Banks to strengthen the supports of the trestles on which the centres rested, but his requests had not been complied with. The cap pieces on the upper cills had been very much weakened at the places where the striking wedges rested, so he instructed them to double the uprights or he would stop the building of the arches. He also noted that the pumps on the eighth pier and Middlesex abutment were driven by sliding rods, not chains, which caused a reciprocating motion that had shaken the cofferdams, so he instructed them to use chains, as in the London docks. And, apparently with some embarrassment added: 'I must also request on the part of the Company that you keep the steam engines in better repair and use Russia tallow for greasing the rods in place of fish oil' (ICE, 1813c).

The second half of 1813 saw a delay to the seventh pier, in order to minimise interruption to river traffic, until some cofferdams of the earlier piers had been removed, which Rennie felt was justified as the Thames Navigation had hitherto cooperated most handsomely with the bridge company. A more serious problem

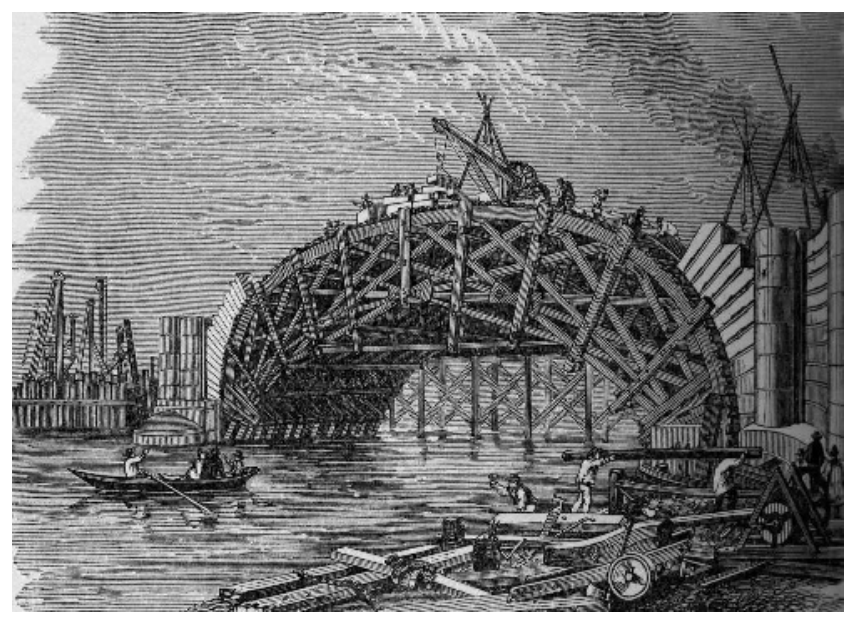

Figure 6. The first arch of Waterloo Bridge under construction (Smiles, 1862) 
Engineering History and Heritage

Volume 164 Issue EH3
John Rennie and Waterloo

Bridge, London

Ruddock was becoming apparent though: $271210 \mathrm{cu} . \mathrm{ft}\left(7679 \cdot 8 \mathrm{~m}^{3}\right)$ of granite had been supplied by Grey \& Co. from their quarries in Cornwall in 3 years, but a further $270497 \mathrm{cu}$. $\mathrm{ft}\left(7660 \mathrm{~m}^{3}\right)$ would be needed by Christmas 1814 if the works were to be completed on schedule. And even if the quarries could raise their output, the harbour at Penrhyn would not be able to ship it at the rate required. He therefore suggested using stone from Craigleith, near Edinburgh, for the middle parts of the arches, as it was not very different in colour (ICE, 1813d).

From the 42nd course upwards, the masonry of the arch rings was laid in echelon fashion, with that along the centre line of the bridge leading. Between 200 and $300 \mathrm{t}$ of stone had been laid on the tops of the centres to resist upward movement as the masonry was placed in position on the haunches. On 7 May 1814, the central keystone of the first arch was placed in position, 'fitting in as if it had been made on the spot, giving general satisfaction to all concerned', as George Rennie noted (NLS, 1814). There clearly had been some doubts about the centres. The rest of the arch ring was brought up to completion on 25 May.

Work now continued to a routine. When the time came to remove a centre, the wedges between the trestles and the centre were pushed back by a wooden weight swung from an iron frame on the centre, then the centre itself was lifted onto a barge by screw jacks and set up further along the bridge (Figure 7). But on 23 June 1815, while removing the centring of the fifth arch, four ribs fell. Rennie ascribed this to (over)confidence acquired by a series of successful operations. Although the contractors suffered a loss, the bridge was not damaged and progress not delayed. The arch rings of the eighth and ninth arches were completed on 28 November 1815 , as Rennie had predicted more than 3 years earlier, but there was still much to do. Negotiations with the Duchy of Lancaster were still proceeding for land for the northern approaches, so although the road over the bridge could be completed soon and the southern approach also, Rennie thought that there was no point in spending money on the southern approaches yet (ICE, 1815).

Even by June 1816, with the spandrel walls complete, the company was still not in full possession of land for the north approach (ICE, 1816a). To add insult to injury, a complaint was received from C. B. Bathurst, the chancellor of Duchy of Lancaster, that the road had been set out nearer by $12 \mathrm{ft}$ $(3.7 \mathrm{~m})$ to Somerset House than was allowed in the Act. Rennie had known Bathurst in 1812 when the latter had employed him on behalf of the county of Gloucester to design a new bridge over the River Wye at Chepstow and, although Rennie's bridge was not built, they had parted on good terms. Presumably Bathurst was passing on complaints from the tenants in Somerset Place whose houses had suffered earlier from the construction of the Middlesex abutment cofferdam. Rennie had a survey made quickly and had to admit that parts of the wing walls and watermen's stairs were closer than the $60 \mathrm{ft}$ $(18 \cdot 3 \mathrm{~m})$ minimum, but pointed out that the Act referred only to the road (ICE, 1816b). It might have been difficult to move the bridge at that stage.

Land at the south end was not available until June 1816 and at the north end finally in November (ICE, 1816c) Work on the approaches pushed ahead; the waterproof layer of clay and the road metalling was laid on the bridge proper and the works on both brought to a conclusion together. The bridge was opened

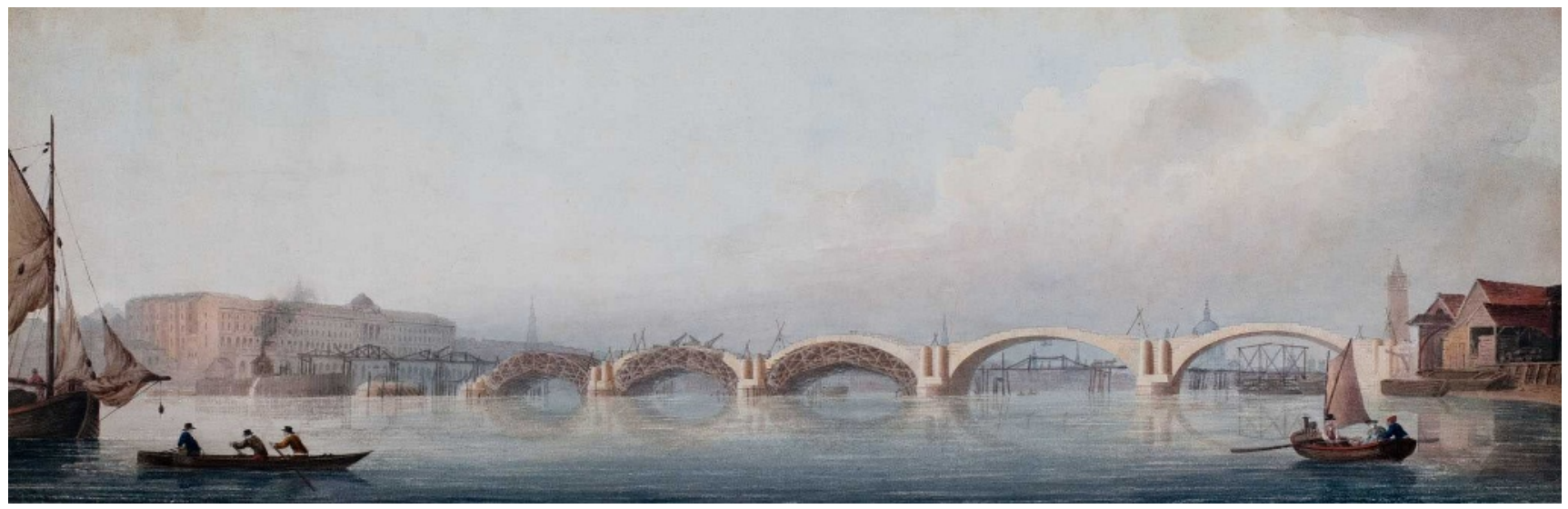

Figure 7. Waterloo Bridge under construction in 1814. Three sets of centres were transferred along the bridge as arches were completed. Temporary access in the background. From the ICE Archives 
Engineering History and Heritage

Volume 164 Issue EH3
John Rennie and Waterloo

Bridge, London

Ruddock

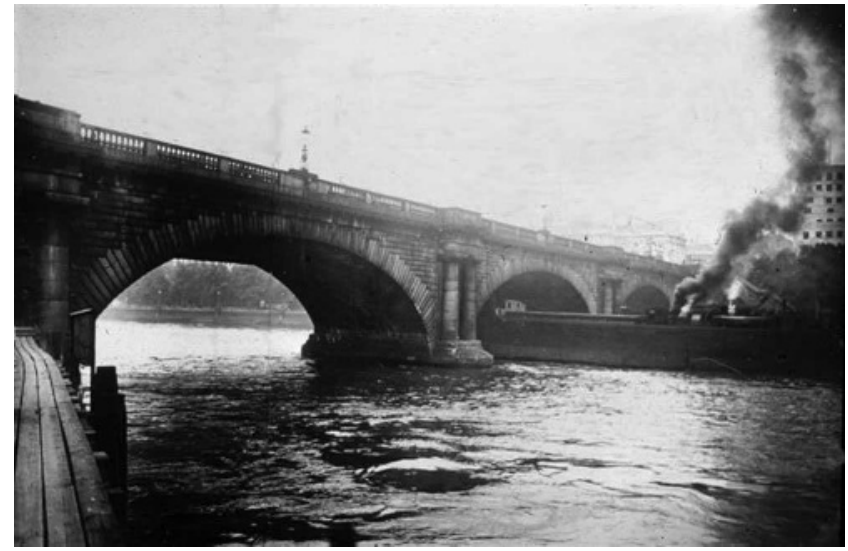

Figure 8. Waterloo Bridge late in life

on 18 June 1817, the second anniversary of the Battle of Waterloo. The ceremony was conducted with great pomp by the Prince Regent, with the Duke of Wellington in attendance. Rennie was offered a knighthood, from which, he recorded, he escaped with difficulty.

\section{Later works}

After Waterloo Bridge only a handful of large masonry road bridges were built in Britain (Ruddock, 1979: pp. 175-200). Rennie's treatment for Ken Bridge at New Galloway, designed in 1820 , was much simpler than any of his earlier bridges, due partly no doubt to the client's lack of funds, though it is still a very elegant structure. The design of the new London Bridge is usually ascribed to Rennie, though it was not built until 1824-1831, after Rennie's death. His eldest son George claimed to have made the design in 1820 for his father, and later gave his opinion that the architecture of bridges in London should be simple and bold, and devoid of insignificant ornament, as London Bridge was.

In the 1820 s and 1830s, Thomas Telford was responsible for a number of markedly different designs, each of which owed little or nothing to Rennie. Over Bridge at Gloucester has a single $150 \mathrm{ft}(45.7 \mathrm{~m})$ arch in the tradition of Perronet's Pont de Neuilly, which Jessop and Rennie had condemned when considering Dodd's initial concept for Waterloo Bridge. The new Broomielaw Bridge in Glasgow, which Sir Alexander Gibb later considered to be perhaps the most beautiful of all Telford's bridges (Gibb, 1935: p. 260) had seven arches of up to $58 \mathrm{ft} 6$ in $(17 \cdot 8 \mathrm{~m})$ span. This was rather conservative for the time, but allowing a very gentle rise from the abutments to the centre of the bridge. Much more daring were his two viaducts, then still a relatively rare form - Lothian viaduct at Pathhead and Dean Bridge in Edinburgh.

Rennie's tradition was, however, carried over to the Grosvenor Bridge at Chester, whose $200 \mathrm{ft}(61 \mathrm{~m})$ span was the largest masonry arch in the world for many years. It was designed originally by Thomas Harrison, the architect whose Skerton Bridge Rennie had admired at Lancaster back in 1784 on his first trip south, but George Rennie was consulted in 1825 and made significant changes both to the form of the abutments and the depths of the arch ring. It was built successfully in 1827-1833 by James Trubshaw junior (Skempton et al., 2002: pp. 727-728), son of one of the contractors who had given up his contract on Rennie's Wolseley Bridge in 1799.

When Rennie and Jessop had reported on Dodd's design in 1809 they had written (ICE, 1809):

We have also known that for want of weight on the salient ends of the piers, they have in some cases entirely separated from the body of the bridge \& in others, when for want of the requisite strength in the spandril walls they have yielded outwards. Some sort of building should therefore be placed on the salient projections of the piers for the treble purpose of giving an equality of weight as far as may be on the foundations, strength to the spandril walls \& ornament to the bridge.

It was ironic therefore that, in the 1930s, because the foundations of the piers flared out too quickly, the salient projections of one of the piers of Waterloo Bridge did indeed become detached from the rest of the bridge as the main body slowly subsided (Figure 8). Despite vociferous protests, the bridge was demolished and replaced by the present reinforced concrete structure.

\section{REFERENCES}

Cresy E (1847) Encyclopaedia of Civil Engineering. Longman, Brown, Green \& Longmans, London. Vol. 1 republished 2010, Thomas Telford, London, doi: 10.1680/ aeocehtpvi.36352.

Gibb A (1935) The Story of Telford. Alexander Maclehose \& Co., London.

ICE (Institution of Civil Engineers) (1809) ICEgen. ICE, London. ICE (1812a) ICE7, 86. ICE, London.

ICE (1812b) ICE7, 84. ICE, London.

ICE (1812c) ICE7, 178. ICE, London. ICE (1813a) ICE7, 288. ICE, London. ICE (1813b) ICE7, 297. ICE, London. ICE (1813c) ICE7, 301. ICE, London. ICE (1813d) ICE7, 354. ICE, London. ICE (1815) ICE8, 285. ICE, London. ICE (1816a) ICE8, 360. ICE, London. ICE (1816b) ICE8, 393. ICE, London. ICE (1816c) ICE8, 425. ICE, London. NLS (National Library of Scotland) (1784) Ms 19831. NLS, Edinburgh.

NLS (1811) Ms 19777. NLS, Edinburgh. NLS (1813) Ms 19777. NLS, Edinburgh. NLS (1814) Ms 19777. NLS, Edinburgh. Rennie J (1784) Life of John Rennie. Institution of Civil Engineers Archives, London. 
Ruddock EC (1974) Hollow spandrels in arch bridges: a historical study. Structural Engineer 52(8):

281-293.

Ruddock EC (1979) Arch Bridges and their Builders, 1735-1835. Cambridge University Press, Cambridge.

Skempton AW, Chrimes MM, Cox RC et al. (eds) (2002)
Biographical Dictionary of Civil Engineers in Great Britain and Ireland. Volume 1: 1500-1830. Thomas Telford, London.

Smiles S (1862) Lives of the Engineers, volume II. John Murray, London. Reprinted 1968, David \& Charles, Newton Abbot.

\section{WHAT DO YOU THINK?}

To discuss this paper, please email up to 500 words to the editor at journals@ice.org.uk. Your contribution will be forwarded to the author(s) for a reply and, if considered appropriate by the editorial panel, will be published as discussion in a future issue of the journal.

Proceedings journals rely entirely on contributions sent in by civil engineering professionals, academics and students. Papers should be 2000-5000 words long (briefing papers should be 1000-2000 words long), with adequate illustrations and references. You can submit your paper online via www.icevirtuallibrary.com/content/journals, where you will also find detailed author guidelines. 